\title{
A Redescription of Sciasmomyia supraorientalis (Insecta: Diptera: Lauxaniidae), the First Recorded Genus and Species in Korea
}

\author{
Hyun-Suk Lee and Ho-Yeon Han* \\ Division of Biological Science and Technology, Yonsei University, Wonju-si, \\ Gangwon-do 220-710, Korea
}

\begin{abstract}
The genus Sciasmomyia (Diptera: Lauxaniidae) was discovered for the first time in Korea. This Old World (PA and OR) genus currently includes two nominal species. In the process of revising Korean Lauxaniidae, we were able to collect Korean representatives of Sciasmomyia supraorientalis, and provide the redescriptions and illustrations of both sexes.
\end{abstract}

Key words: Diptera, Lauxaniidae, taxonomy, Sciasmomyia supraorientalis

\section{INTRODUCTION}

The genus Sciasmomyia was erected by Hendel (1907) based on the type species, Sciasmomyia meijerei Hendel. In the same paper, he described $S$. dichaetophora as an additional new species. Shewell (1971) recognized considerable difference between $S$. meijerei and $S$. dichaetophora and erected the new genus Sciasminettia for S. dichaetophora. Sciasmomyia currently includes two nominal species: $S$. meijerei Hendel and S. supraorientalis (Shatalkin, 2000).

This genus can be distinguished from the other genera of Lauxaniidae by the combination of the following characteristics (modified from Shatalkin, 2000): 1) face grayish brown with three protuberances; 2) median protuberance with grayish brown band on upper half; and 3) body grayish brown with dark brown spots.

In the process of revising Korean Lauxaniidae, we have identified a number of specimens of $S$. supraorientalis for the first time in Korea. This is also the first record of the genus in Korea. We here provide redescriptions and illustrations of both sexes.

\section{MATERIALS AND METHODS}

Terminology and morphological interpretations follow the glossary of Merz and Haenni (2000), but those of male ter-

\footnotetext{
*To whom correspondence should be addressed

Tel: 82-33-760-2254, Fax: 82-33-760-2183
}

E-mail: hyhan@yonsei.ac.kr minalia follow Sinclair (2000). In addition, we use the following 12 ratios modified from Han and Norrbom (2005): vertexhead ratio (vertex width / head width); eye-vertex ratio (eye width/vertex width); eye ratio (shortest eye diameter/longest eye diameter); frons-head ratio (narrowest width of frons in dorsal view/width of head); gena-eye ratio (genal height/ longest eye diameter) - genal height is the distance between the ventral eye margin and the ventral genal margin anterior to the genal seta; gena-parafacialia ratio (genal height/parafacialia width); flagellomere 1-pedicel ratio (length of flagellomere $1 /$ length of pedicel); arista-antenna ratio (lenth of arista/length of antenna excluding arista); vein $\mathrm{R}_{4+5}$ ratio (distance along vein $\mathrm{R}_{4+5}$ between crossvein $\mathrm{R}-\mathrm{M}$ and vein $\mathrm{R}_{4+5}$ apex/distance between crossvein $\mathrm{R}-\mathrm{M}$ and basal node of vein $R_{4+5}$ ); vein $M$ ratio (distance along vein $M$ between crossveins R-M and DM-Cu/distance between crossveins R$\mathrm{M}$ and $\mathrm{BM}-\mathrm{Cu}$ ); subcosta-costa ratio (length of pterostigma/ length of costal cell, both measured along vein $\mathrm{C}$ ); wingthorax ratio (wing length/thorax length).

All the examined specimens are deposited in the Division of Biological Science and Technology, Yonsei University, Wonju Campus, Korea (YSUW).

\section{SYSTEMATIC ACCOUNTS}

Order Diptera

Family Lauxaniidae Latreille, 1804

Genus Sciasmomyia Hendel, 1907

Sciasmomyia Hendel, 1907: 233. Type species: Sciasmomyia meijerei Hendel. 
${ }^{1 *}$ Sciasmomyia supraorientalis (Papp) (Figs. 1, 2)

Lyciella (Shatalkinia) supraorientalis Papp, 1984: 172 (typelocality: Primorsky Krai, Khasan Region, Kedrovaya Pad Biosphere Reserve, Russia; holotype $\sigma^{7}$, Zoological Museum, University of Moscow).

Sciasmomyia (Shatalkinia) supraorientalis: Shatalkin, 2000: 42 (in Palaearctic key); Schacht, Kurina, Merz and Gaimari, 2004: 59 (English translation of Shatalkin, 2000: 42).

Material examined. KOREA: Gyeongsangbuk-do: $2 o^{7} o^{7}, 1$ 우, Yeongju-si, Sunheung-myeon, Sobaeksan Mt. from Choamsa to Gukmangbong 1,421 m peak, 21-V-2007 (H.S. Lee, S.W. Suk and J.S. Lim); $10^{7}$, 4 우 우, Seongju-gun, Suryun-myeon, Gayasan Mt. National Park from Baekun-ri to Sangwangbong 1,430 m peak, 23-VIII-2007 (J.S. Lim, Y.B. Lee and J.M. Jung). Gyeonggi-do: $1 \sigma^{7}$, Pocheon-si, Gasan-myeon, Ugeum-ri, 23-VII-2006 (D.S. Choi et al.). Gyeongsangnam-do: 11 $^{7}$ $^{7}, 17$ 우 우, Hapcheon-gun, Gayamyeon, Gayasan Mt. National Park from Haein Temple to Sangwangbong 1,430 m peak, 23-VIII-2007 (H.S. Lee, S.W. Suk and D.J. Cha). Gangwon-do: 3 우 우, Chuncheon-si, Buksan-myeon, Jogyo-ri, 2-VI-2006 (D.S. Choi et al.); 1 우, Chuncheon-si, Dong-myeon, Wolgok-ri, 3-VI-2006 (D.S. Choi et al.); 1 우, Chuncheon-si, Dongsan-myeon, Wonchang-

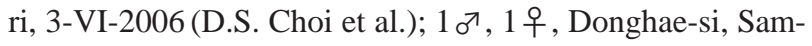
hwa-dong, Mureung valley, 26-V-2007 (H.S. Lee et al.); $10^{7}$, 1 우, Hoengseong-gun, Dunnae-myeon, Cheongtaesan Mt. from Sapgyo-ri to 1,200 m peak, 18-VI-2005 (H.Y. Han et al.); $10^{7}, 6$ 우 우, Hongcheon-gun, Nae-myeon, Changchon-ri, North valley of Gyebangsan Mt., 23-VI-2005 (H.S. Lee); $1 \sigma^{7}$, ditto, 22-VII-2005 (H.S. Lee); $1 \sigma^{7}$, ditto, 5-VIII-2005 (H.Y. Han and H.S. Lee); 1 우, ditto, 26-V-2006 (H.S. Lee and D.J. Cha); 1 우, ditto, 30-VI-2006 (H.Y. Han and H.W. Byun); $10^{7}, 4$ 우 우, Hongcheon-gun, Nae-myeon, Gachilbong Mt., Sambongyaksu, 17-VI-2005 (D.S. Choi, H.S. Lee and S. Hwang); $1 \sigma^{7}, 1$ 우, Jeongseon-gun, Nam-myeon, Mindungsan Mt. from Yupyeong-ri to 1,119 m peak, 7-VI-2007 (H.Y. Han and S.W. Suk); 1 우, ditto, 7-VII-2007 (H.Y. Han et al.); $1 \mathrm{o}^{7}, 2$ 우 우, Wonju-si, Heungeop-myeon, Maeji-ri, Yonsei Univ. Campus, 22-VI-2005 (Bernhard Merz); 1 우, ditto, 25VI-2005 (H.S. Lee); 2 우 우, ditto, 13-VI-2006 (H.S. Lee); 2 우 우, ditto, 19-III-2007 (S.W. Suk); $10^{7}, 1$ 우, ditto, 29-III2007 (S.W. Suk); $1 \sigma^{7}, 1$ 우, ditto, 9-IV-2007 (H.S. Lee and J.S. Lim); 1 우, ditto, 9-IV-2007 (S.W. Suk); 1 o $^{\text {}}$, ditto, 11IV-2007 (H.S. Lee); 1 우, ditto, 14-IV-2007 (S.W. Suk); 1 $0^{7}, 1$ 우, ditto, 16-IV-2007 (J.S. Lim); 1 乃 $^{7}, 1$ 우, ditto, 19-IV2007 (H.S. Lee); $10^{7}, 1$ 우, ditto, 28-V-2007 (H.S. Lee and J.S. Lim).

Diagnosis. This species can be distinguished from the only congener, S. meijerei, by the combination of the following characteristics (modified from Shatalkin, 2000): 1) scutellum gray with pair of black spots at apex (Fig. 1C); and 2) wing with dark brown spots on apices of Sc, R and $\mathrm{M}$ veins (Fig. 1B).

Redescription of Male. Body grayish brown in ground color with numerous brown spots in varying size; setae black; setulae mostly black except for tiny whitish setulae on eyes and golden setulae on labella; body length $4.35-4.83 \mathrm{~mm}$; wing length 4.85-5.00 mm. Head (Fig. 1D, E) predominantly grayish brown with gray pruinosity; head-vertex ratio $0.42-0.45$, eye-vertex ratio $0.60-0.69$, frons-head ratio $0.47-0.49$, eye ratio $0.66-0.83$, gena-eye ratio $0.13-0.17$, gena-parafacialia ratio $0.80-1.00$, flagellomere 1-pedicel ratio 4-6, arista-antenna ratio 1.76-1.93; eye with sparsely short whitish setulae; medial vertical setae strong, reclinate, $0.70-0.80 \times$ longest diameter of eye; lateral vertical setae strong, lateroclinate, $0.69-0.85 \times$ as long as medial vertical setae; strong ocellar setae proclinate, $0.66-0.78 \times$ as long as medial vertical setae; postocellar setae $0.50-0.58 \times$ as long as medial vertical setae; vertex with 3-4 short setulae; frons sparsely covered with short setulae; one strong reclinate anterior fronto-orbital seta; one strong reclinate posterior fronto-orbital seta; antennal scape yellow brown; pedicel yellow brown, dorsally with one long seta, ventrally with two long setae and relatively short setulae on apical margin; flagellomere 1 yellow brown, golden pubescent; arista dark brown, plumous; parafacialia with two dark brown (mid and low) spots, bare; face with three dark brown longitudinal bands, with three protuberances (one middle and two lower lateral); gena with dark brown spot with 5-8 weak subvibrissal setulae; postocular setae extended half distance from dorsal eye margin to ventral eye margin; occiput sparsely setulose; clypeus dark brown, U-shaped; mouthparts with palpus black, slightly clavate with apical and ventral setulae; prementum yellow brown with posterior setulae; labella dark brown with many wrinkles and golden setulae. Thorax grayish brown in ground color with gray pruinosity; scutum with $1+4$ acrostichal, $1+3$ dorsocentral, 1 presutural, 1 supraalar, 2 postalar setae; basal areas of most scutal setae and setulae darker than nearby areas of scutum; presutural scutum with 2 rows of short acrostichal setulae and sparsely with short setulae between postpronotal lobe and presutural dorsocentral seta; postsutural scutum sparsely with short setulae between supraalar and dorsocentral setae; prosternum yellow brown, bare; postpronotal lobe with single seta and short sparse setulae; notopleuron with 2 strong setae; proepisternum with one strong seta; anepisternum with one posteriorly directed seta and short sparse setulae; katepisternum with 2 strong setae

\footnotetext{
$1 *$ 얼룩큰날개파리 (신칭)
} 


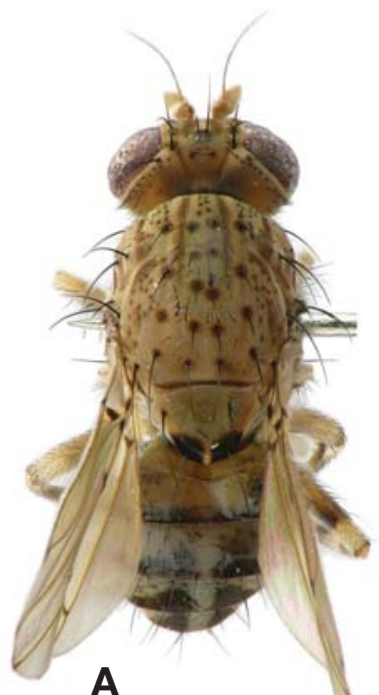

A
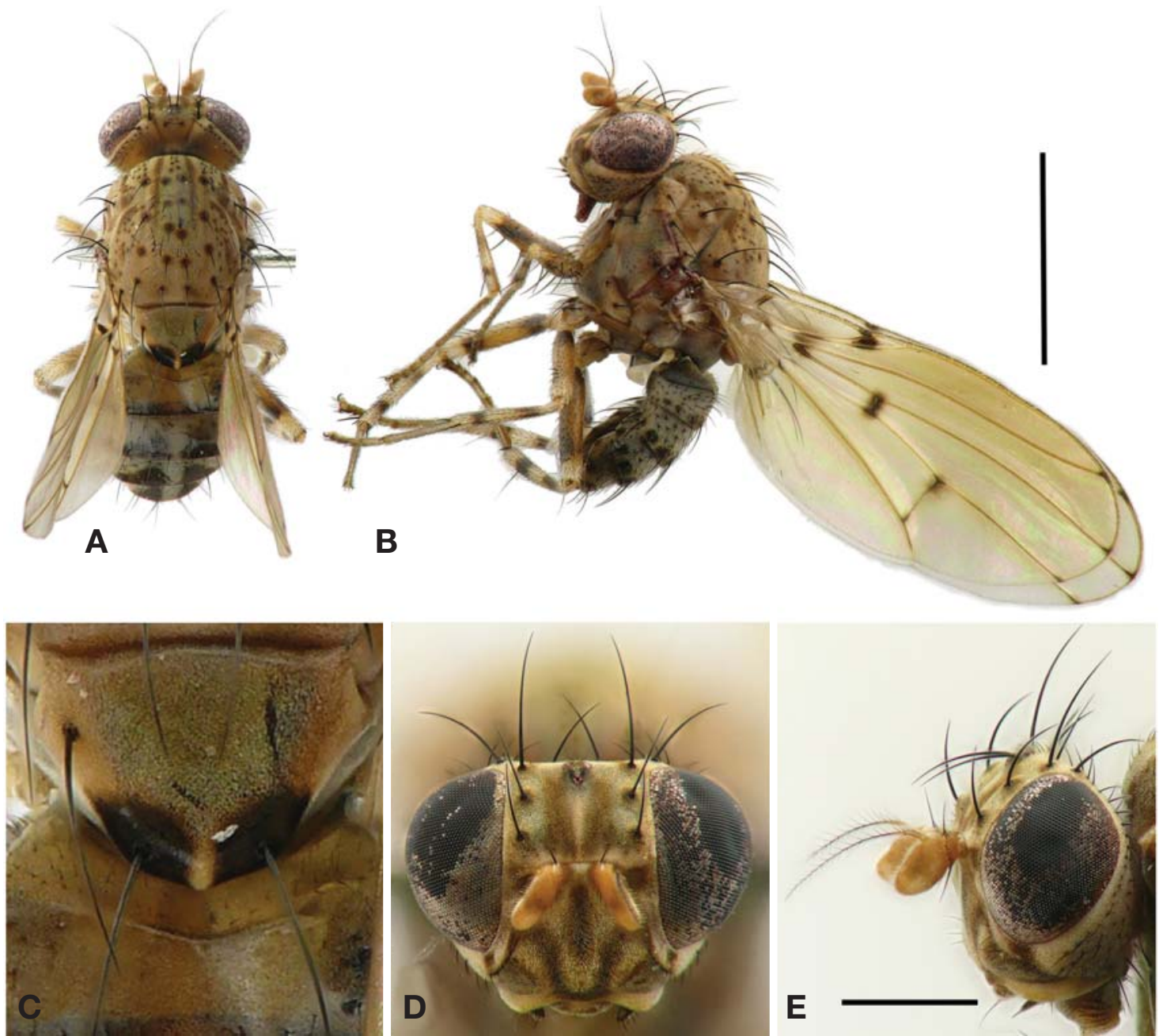

Fig. 1. Sciasmomyia supraorientalis. $A-E$, female. Scale bars $=2 m m(A, B), 0.6 m m(D, E)$.

and relative long setulae ventrally; anepimeron bare; meron bare; katatergite bare; anatergite bare; scutellum with pair of large black spots at apex, with basal setae convergent, and apical setae divergent. Legs yellow brown in ground color with some dark brown areas; fore coxa with gray pruinosity, short setulose, anteriorly with row of long setulae; fore femur with dark brown basal and preapical areas, with gray pruinosity, posteriorly with rows of long posterodorsal, posterior, posteroventral setae; fore tibia with dark brown subbasal and preapical areas, with single long dorsal preapical seta; midcoxa anteriorly with row of long setulae; midfemur with dark brown basal and preapical areas, with gray pruinosity, anteriorly with row of 4-5 mesal setae; midtibia dark brown subbasal and preapical areas, with long dorsal preapical seta apicad of darkened area; with single apicoventral spur twice as long as tibial width; hind coxa with gray pruinosity, setulose; hind femur with dark brown basal and preapical areas, with gray pruinosity, with single anterior preapical seta; hind tibia dark brown subbasal and preapical areas, with single long dorsal preapical seta, with single apicoventral spur $1.5 \times$ as long as tibial width. Wing hyaline with brownish tinge and with dark brown spots on following areas: humeral crossvein, basal half of subcostal cell, fork of $\mathrm{R}_{2+3}$ and $\mathrm{R}_{4+5}$ veins and faintly anterior to it, around $r-m$ vein, around $d m-c u$ joined with $M$ vein; tiny spots at apices of $R_{2+3}, R_{4+5}$, $M$ veins and posterior part of dm-cu vein; veins yellow brown; tegula yellow brown with setulae; wing-thorax ratio 2.30-2.46; vein $\mathrm{R}_{4+5}$ ratio 2.46-3.06; vein $\mathrm{M}$ ratio 0.66-0.83; subcostalcostal ratio 0.24-0.32; costa with one strong basal seta about $5 \times$ as long as costal setulae; costal setulae reach slightly beyond apex of $\mathrm{R}_{2+3}$; haltere yellow brown. Abdomen grayish brown in ground color with dark brown spots, with gray pruinosity; tergites $1+2$ with narrow dark brown posterior marginal band; tergites 3-5 each with pairs of large triangular 

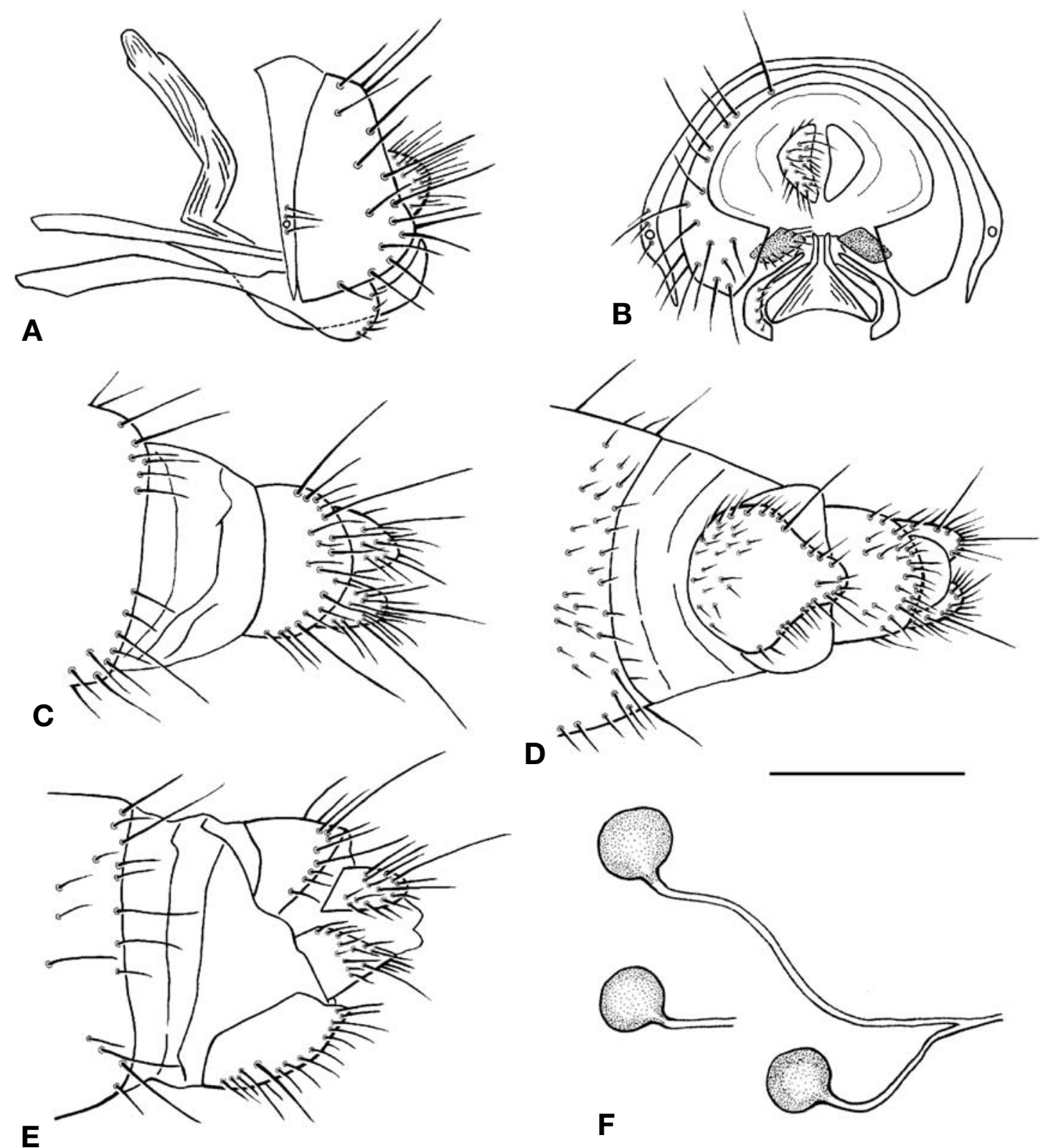

Fig. 2. Sciasmomyia supraorientalis. A, male genitalia, lateral view; B, male genitalia, caudal view; C, female postabdomen, dorsal view; $D$, female postabdomen, ventral view; E, female postabdomen, lateral view; F, spermatheca. Scale bar=0.3 mm.

discal and small round lateral spots; tergite 6 with pair of dark brown spots in varying shape. Genitalia (Fig. 2A, B) yellow brown to dark brown; epandrium yellow brown, strongly setulose; cercus yellow brown, densely setulose; surstylus dark brown, more or less in oblong shape, about $2 / 3$ as long as cerci in caudal view, mesally with row of weak marginal setulae; hypandrium apically round in lateral view, predominantly yellow brown with weak apical setulae; aedeagal complex with pair of apicodorsally pointed processes.
Female. Similar to males except for the following postabdominal characters (Fig. 2C-F): supra-anal plate semicircular in dorsal view, more or less triangular in later view; circus tapering toward apex, slightly shorter than subanal plate; subanal plate semicircular in ventral view, more or less triangular in later view; three spermathecae round with short basal neck, yellow brown with smooth surface. Lengths and ratios: body length 4.50-4.64 $\mathrm{mm}$ and wing length $4.80-5.30 \mathrm{~mm}$. head-vertex ratio $0.41-0.44$, eye-vertex ratio $0.63-0.71$, eye 
ratio $0.70-0.83$, frons-head ratio $0.45-0.48$, gena-eye ratio $0.12-0.15$, gena-parafacialia ratio $0.80-1.00$, flagellomere 1 pedicel ratio 3.67-4.00, arista-antenna ratio 1.63-1.94; medial vertical setae $0.69-0.76 \times$ longest diameter of eye; lateral vertical setae $0.76-0.86 \times$ as long as medial vertical setae; ocellar setae $0.63-0.78 \times$ as long as medial vertical setae; postocellar setae $0.52-0.60 \times$ as long as medial vertical setae. Distribution. Korea, Japan (Kyushu), Russia.

\section{ACKNOWLEDGEMENTS}

We thank K.-E. Ro, B. Merz, D.-S. Choi, H.-W. Byun, S.-W. Suk, J.-S. Lim, D.-J. Cha, J.-M. Jung and Y.-B. Lee for their assistance to collect $S$. supraorientalis. This study was supported by the Korean Ministry of Environment (the Eco-technopia 21 Project and the Survey of Indigenous Biological Resources of Korea Project, NIBR).

\section{REFERENCES}

Han, H.Y. and A.L. Norrbom, 2005. A systematic revision of the New World species of Trypeta Meigen (Diptera: Tephritidae). Systematic Entomology, 30: 209.
Hendel, F., 1907. Neue und interessante Dipteren aus dem kaiserl. Museum in Wien. Wiener Entomologische Zeitung, 26: 233-235.

Merz, B. and J.P. Haenni, 2000. 1.1. Morphology and terminology of adult Diptera (other than terminalia). In Papp, L. and B. Dravas, eds., Contribution to a Manual of Palaearctic Diptera. Science Herald, Budapest, pp. 21-51.

Papp, L., 1984. Lauxaniidae (Diptera), new Palaearctic species and taxonomical notes. Acta Zoologica Hungarica, 30: 172174.

Schacht, W., O. Kurina, B. Merz and S. Gaimari, 2004. Zweiflugler aus Bayern XXIII (Diptera: Lauxaniidae, Chamaemyiidae). Entomofauna Zeitschrift Fur Entomologie, 25: 59.

Shatalkin, A.I., 2000. Keys to the Palaearctic flies of the family Lauxaniidae (Diptera). Zoologicheskie Issledovania, 5: 4142.

Shewell, G.E., 1971. Ergebnisse der zoologischen Forschungen von Dr. Z. Kaszab in der Mongolei. 264. Diptera: Lauxaniidae. Stuttg. Beitr. Naturk., 224: 1-12.

Sinclair, B.J., 2000. 1.2. Morphology and terminology of Diptera male terminalia. In Papp, L. and B. Dravas, eds., Contibution to a Manual of Palaearctic Diptera. Science Herald, Budapest, pp. 53-74.

Received June 17, 2009 Accepted June 30, 2009 